\title{
DIANA MARY RUSTAT ROWLEY, NÉE CROWFOOT (1918-2018)
}

Diana Rowley celebrated her 100th birthday on 21 June this year and left us almost exactly three months later. She retained quick wits and a clear memory throughout her life, one that was flavoured with persistent cheerfulness. She grew up in a brilliant family. Her father was Principal of Gordon College and Director of Antiquities for the Sudan when she was born in Khartoum, the youngest of four girls. Her eldest sister Dorothy (Crowfoot Hodgkin) won the Nobel Prize for chemistry in 1964. Diana's formal education began early, for she was sent to boarding school in southern England at the age of four, an experience that might have formed or reinforced her personal resilience, so evident in the last 10 years. We might be shocked by the separation from her parents at such a tender age, but then it was not uncommon for children to be at "home" for their education.

Diana edited the journal Arctic for the Arctic Institute of North America (AINA) from 1949 to 1955 (Vol. 2, No. 2 to Vol. 8, No. 1), at a time when Arctic research was evolving from its pre-war expeditionary modus operandi to more consistent programs facilitated by post-war logistics. Editing was her particular skill. She had become proficient at the Royal Geographical Society, where she was appointed as assistant editor of the Geographical Journal in 1941, after going down from Oxford. She had read Natural Sciences at Somerville in 1936-39. At Arctic she published articles by scientists whose names still resonate: A.W.F. Banfield, H.S. Bostock, M.J. Dunbar, R.F. Flint, R.F. Leggett, and A.E. Porsild. Some of the articles (e.g., Rausch, 1953) approached monograph length, and some (e.g., Manning, 1953) had improbable titles. Conducting her work from home, she took the journal from three to four issues per year in 1952, her address printed on the back cover of each issue. Only from 1955 on were articles to be sent to the Institute. She composed a considerable amount of the copy in the news sections of the journal. One item is a prescient note regarding a trial for matricide, The Death of Nukashook, sympathetically treating the conflict between traditional practices born out of necessity and the imposition of Canadian law (Rowley, 1949). She left Arctic to become the founding editor of AINA's Technical Papers, a monograph series that included 23 contributions in her time (1956-70) from J.C. Ritchie, C.J. Krebs, G.K.C. Clarke and others, and a series of lengthy reports by Diamond Jenness on Eskimo Administration. In this light, she played a remarkable role in the formative years of modern Arctic research with some of the leading scientists of Canada, a role that is today unfortunately unacknowledged. In 1954 she was elected a Fellow of AINA.

After the war, Diana came to Canada with Graham, whom she had married in 1944, and their first daughter, Anne. It was to be a long and happy relationship with him and with Canada. He had served in the Canadian Army and spent the majority of his subsequent career on federal arctic matters, so they lived in Ottawa. Graham had first

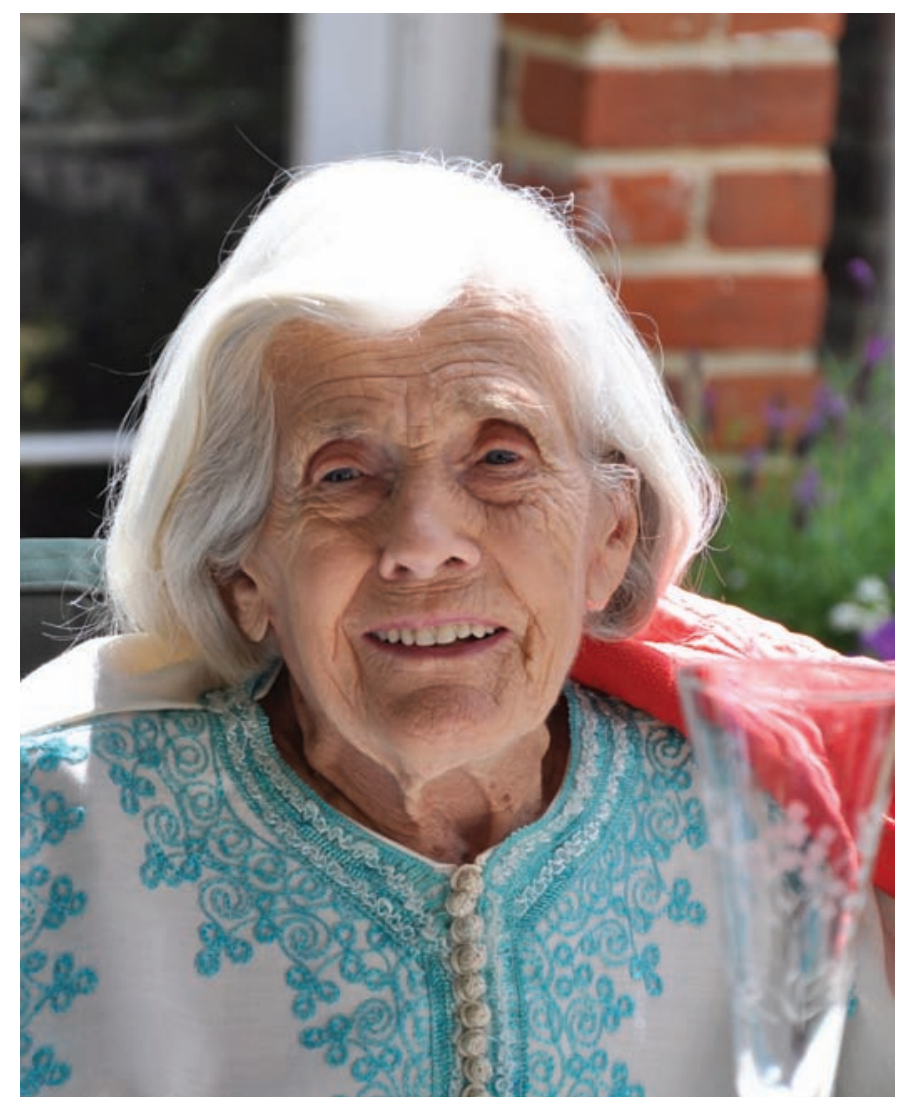

Diana Rowley (photo taken by her grandchild Sarah Townrow).

come to Canada and worked in the Foxe Basin area as an archaeologist before the war (MacDonald, 2004), and Diana grew to share his experiences in our eastern Arctic and affection for its people. Their second daughter, Susan, has similarly enriched Arctic archaeology. Diana, with Graham, supported Susan in the field when she and Carolyn MacDonald organized the Igloolik Archaeology Field School(s) in 1987 and 1990-96. The Rowley home had for many years been a focal point for Arctic people in Ottawa or while visiting the city. It was an unjudgmental place, where people were valued for what they brought to a conversation. Diana was a consummate listener and conversationalist, setting people at ease, and open to their stories. Their home exemplified a time and place when and where personal and professional relationships blended with ease. In the Arctic, her relationships with Northerners blossomed.

In 1947, the Rowleys and Tom and Jackie Manning founded the Arctic Circle Club as a discussion group that met once a month from October to April to hear a talk and meet like-minded friends. An organizational meeting occurred in mid-November of that year, and the first official meeting took place on 8 December with 100 people attending (Burn, 2014). They also founded the Arctic Circular, a mimeographed newsletter-cum-journal for the Circle, which Diana edited and produced from its inaugural issue in January 1948 until 1967. It is now available online 
(http://www.thearcticcircle.ca/library.html). There is much, much more in it than we might think with the passage of time, largely because of Diana's grasp of what might be worth reading and how it should be written. There was cross-fertilization between the Arctic Circular and Arctic, partly driven then by the paucity of accurate information emanating from the North. An explanatory tribute to her on page 2 of the 1968 volume of the Arctic Circular describes the magnitude of what she accomplished. Diana and Graham spent 1968-69 in Cambridge with their family, which now included their third daughter, Jane. It was a convenient break that allowed her to pass on her editorial responsibilities for the Arctic Circular.

The Arctic Circle continues to gather as originally foreseen and up to the end of 2018 has held 532 meetings and 60 annual dinners. The speakers' roll lists the great and the good of Canadian Arctic research: R.J.E. Brown, H. Brody, A.S. Dyke, R.M. Koerner, J.R. Mackay, E.F. Roots, V. Stefansson, I.G. Stirling, W.F. Vincent, and so on. Diana was a more faithful member than anyone else, attending whenever she could. She sat in the front row, and the speakers sometimes thought she was nodding off. But after the talk, she commonly posed questions that corrected any such impression. She was as keen on clarity in diction as she was in text, and she greatly appreciated those who enunciated precisely and spoke in a well-organized manner. The presidents who chair the Arctic Circle meetings were sometimes gently reminded of her desired standards for presentation. Her last meeting was the annual dinner in late April 2018. It was also the last meeting of the 2017-18 programme.

Diana was a devout Anglican, devoted to her parish church. In November 2008, she had fallen and damaged her pelvis. We were all concerned, but she reappeared about two weeks later in a wheelchair. A fortnight later she was out of the wheelchair with a walker, and in about the same time again progressed to a cane. We were amazed. In mid-January, I congratulated her after a service on her speedy recovery and remarked how several of us were most impressed with her progress. "Well, yes, I am fine," she said, "but the doctors are being most tiresome." "Oh," I replied, "Are they being cautious?" "No," she said, "They won't let me travel." "Surely they can make an arrangement to get you to Vancouver?" I asked, thinking she was going to see Susan. "I've already been there." "Where do you want to go?" I asked, innocently. "The Sudan!" And she did.

\section{ACKNOWLEDGEMENTS}

I am indebted to John Bennett, John MacDonald, and Susan and Jane Rowley for points of information and context.

\section{REFERENCES}

Burn, C.R. 2014. Five hundred meetings of the Arctic Circle. Arctic 67(2):266-268.

https://doi.org/10.14430/arctic4396

MacDonald, J. 2004. Graham Westbrook Rowley (1912-2003). Arctic 57(2):223-224.

https://doi.org/10.14430/arctic498

Manning, T.H. 1953. Narrative of an unsuccessful attempt to circumnavigate Banks Island by canoe in 1952. Arctic 6(3):170-197.

https://doi.org/10.14430/arctic3874

Rausch, R. 1953. On the status of some Arctic mammals. Arctic 6(2):91-148.

https://doi.org/10.14430/arctic3870

Rowley, D. 1949. The death of Nukashook. In: Northern News. Arctic 2(3):201-202.

https://doi.org/10.14430/arctic3989

C.R. Burn

Department of Geography and Environmental Studies Carleton University

1125 Colonel By Drive

Ottawa, Ontario K1S 5B6, Canada

Christopher.burn@carleton.ca 